\title{
Pengaruh Asimetri Informasi, Penekanan Anggaran, Komitmen Organisasi dan Ketidakpastian Lingkungan pada Senjangan Anggaran
}

\author{
Putu Ayu Regita Naraswari ${ }^{1}$ \\ I Made Sukartha ${ }^{2}$ \\ ${ }^{1,2}$ Fakultas Ekonomi dan Bisnis Universitas Udayana (Unud), Bali, Indonesia \\ e-mail: regitanaraswari@gmail.com
}

\begin{abstract}
ABSTRAK
Anggaran merupakan rencana periodik yang disusun untuk periode tertentu. Perbedaan jumlah anggaran yang diajukan oleh bawahan dengan jumlah estimasi yang terbaik dari organisasi adalah senjangan anggaran. Tujuan penelitian ini adalah untuk memberikan bukti empiris pengaruh asimetri informasi, penekanan anggaran, komitmen organisasi dan ketidakpastian lingkungan pada senjangan anggaran. Penelitian ini dilakukan di Hotel Berbintang Kabupaten Badung. Instrumen penelitian yang digunakan adalah kuesioner dengan teknik analisis data yaitu analisis regresi linier berganda. Sampel yang digunakan ditentukan dengan metode nonprobability sampling, yaitu purposive sampling. Berdasarkan hasil penelitian ini ditemukan bahwa asimetri informasi, penekanan anggaran dan ketidakpastian lingkungan berpengaruh positif pada senjangan anggaran. Sedangkan komitmen organisasi berpengaruh negatif pada senjangan anggaran.
\end{abstract}

Kata kunci: Senjangan, asimetri, penekanan, komitmen, ketidakpastian

\section{ABSTRACT}

The budget is a periodic plan prepared for a certain period. The difference in the amount of budget submitted by subordinates with the best number of estimates from the organization is budgetary slack. The purpose of this study is to provide empirical evidence of the influence of information asymmetry, budget emphasis, organizational commitment and environmental uncertainty on budgetary slack. This research was conducted at the Starry Hotel in Badung Regency. The research instrument used was a questionnaire with data analysis techniques namely multiple linear regression analysis. The sample used was determined by the nonprobability sampling method, namely purposive sampling. Based on the results of this study it was found that information asymmetry, budget emphasis and environmental uncertainty had a positive effect on budgetary slack. While organizational commitment has a negative effect on budgetary slack.

Keywords: Slack, asymmetry, emphasis, commitment, uncertainty

\section{PENDAHULUAN}

Anggaran merupakan rencana keuangan periodik yang disusun berdasarkan program yang telah disahkan dan merupakan rencana tertulis mengenai kegiatan suatu organisasi yang dinyatakan secara kuantitatif dan umumnya dinyatakan dalam satuan moneter untuk jangka waktu tertentu. Anggaran mengubah 
Putu Regita Naraswari dan I Made Sukartha. Pengaruh...

perspektif manajer ke depan serta membantu dalam merencanakan dan mengendalikan tindakan (Thien, 2014). Tujuan anggaran adalah membuat perencanaan, memberikan informasi yang dapat digunakan untuk meningkatkan pengambilan keputusan, sebagai tolok ukur yang dapat digunakan untuk evaluasi kinerja, meningkatkan komunikasi dan koordinasi dalam organisasi (Hansen \& Mowen, 2012). Terutama anggaran digunakan untuk mengalokasikan sumber daya secara efisien di setiap bagian organisasi. Atasan memerlukan beberapa informasi tentang organisasi secara keseluruhan untuk melaksanakan hal tersebut (Gilbert-Carreras et al, 2014).

Perbedaan jumlah anggaran yang diajukan oleh bawahan dengan jumlah estimasi yang terbaik dari organisasi adalah senjangan anggaran (Anthony \& Govindarajan, 2007). Dimana manajer sengaja mengatur kewajiban tambahan untuk sumber daya dari anggaran tertentu atau tidak menggunakan kemampuan produktif secara maksimal. Apabila dalam sebuah organisasi menggunakan metode bottom-up sebagai metode penyusunan anggaran. Dimana metode bottomup merupakan metode penyusunan anggaran yang mengikutsertakan manajer menengah kebawah dalam proses penyusunan anggaran. Manajer dapat memanfaatkan situasi ini untuk bertindak opportunistis dengan menyusun target anggaran agar mudah untuk direalisasikan. Sehingga, nantinya manajer dapat meningkatkan kinerjanya dan meningkatkan bonus yang akan diperoleh dari atasan. Terdapat fenomena senjangan yang terjadi pada hotel berbintang di Kabupaten Badung. Fenomena ini dapat dilihat dari target dan realisasi pendapatan asli daerah Kabupaten Badung yang berasal dari pajak hotel. 
Bali merupakan salah satu destinasi kunjungan wisatawan mancanegara maupun domestik. Kondisi alam menjadi salah satu faktor penentu kedatangan para wisatawan yang akan berkunjung ke Bali. Kondisi alam seperti pada tahun 2015 meletusnya Gunung Raung di Jawa Timur yang berakibat pada penerbangan ke Bali menjadi terhambat karena abu vulkanik. Selain itu erupsi Gunung Agung pada tahun 2017 juga berdampak pada jumlah wisatawan yang datang ke Bali. Hal tersebut dapat dilihat pada tabel berikut.

Tabel 1.

Pertumbuhan Kedatangan Wisatawan ke Bali

\begin{tabular}{ccc}
\hline & Jumlah Wisatawan & Pertumbuhan \\
\hline Tahun 2014 & 3.766 .638 & $14,89 \%$ \\
Tahun 2015 & 4.001 .835 & $6,24 \%$ \\
Tahun 2016 & 4.927 .937 & $23,14 \%$ \\
Tahun 2017 & 5.697 .739 & $15,67 \%$ \\
\hline
\end{tabular}

Sumber : bali.bps.go.id, 2018

Kedatangan wisatawan ke Bali juga berimbas pada jumlah wisatawan yang menginap di Hotel. Terjadi penurunan tingkat hunian hotel pada tahun 2015 dan peningkatan yang tidak terlalu signifikan pada tahun 2017 dapat dilihat pada tabel berikut.

Tabel 2.

Rata-rata Tingkat Hunian Hotel

\begin{tabular}{cc}
\hline Tahun 2015 & $58,14 \%$ \\
Tahun 2016 & $61,71 \%$ \\
Tahun 2017 & $62,89 \%$ \\
\hline
\end{tabular}

Sumber : bali.bps.go.id, 2018

Adanya peningkatan rata-rata tingkat hunian hotel berbintang di Bali menyebabkan terjadinya peningkatan pendapatan pajak hotel kabupaten Badung. Berikut data pendapatan pajak hotel kabupaten Badung. 
Tabel 3.

Target dan Realisasi Pendapatan Hotel

\begin{tabular}{ccc}
\hline & Target & Realisasi \\
\hline Tahun 2015 & Rp 1.480.000.000.000,00 & Rp 1.581.052.506.627,56 \\
Tahun 2016 & Rp 1.540.000.000.000,00 & Rp 1.773.684.267.138,73 \\
Tahun 2017 & Rp 1.923.908.489.945,89 & Rp 2.029.984.253.567,13 \\
\hline Sumber: https://badungkab.go.id/instansi/bapenda/pad, 2018 &
\end{tabular}

Penurunan pertumbuhan jumlah wisatawan ke Bali yang cukup signifikan terjadi pada tahun 2015 berimbas pada tingkat hunian kamar hotel berbintang yang ada di Bali. Hal ini menunjukkan bahwa tingkat persaingan yang tinggi antar hotel semakin ketat. Dapat dilihat pada Tabel 3 terjadi senjangan pada pendapatan daerah kabupaten badung yang berasal dari pajak hotel. Pajak hotel dipungut atas pelayanan yang disediakan oleh hotel dengan pembayaran, termasuk jasa penunjang sebagai kelengkapan hotel yang sifatnya memberikan kemudahan dan kenyamanan. Dengan dasar pengenaan pajak hotel sebesar $10 \%$ yang berasal dari jumlah pembayaran yang seharusnya dibayar kepada hotel. Dapat diperkirakan penjualan di hotel-hotel kabupaten Badung juga mengalami senjangan antara target dan realisasinya.

Ada beberapa faktor yang dapat menyebabkan terjadinya senjangan anggaran. Menurut Alfebriano (2013) terdapat 5 faktor yang menyebabkan senjangan anggaran, yakni Partisipasi Anggaran, Informasi Asimetri, Penekanan Anggaran, Komitmen Organisasi dan Ketidakpastian Lingkungan. Partisipasi Anggaran merupakan proses dimana individu-individu dalam suatu organisasi ikut serta terlibat dalam menentukan target anggaran. Partisipasi penyusunan anggaran dilakukan dengan tujuan agar anggaran yang ditetapkan nantinya bisa sesuai dengan keadaan yang terjadi. 
Informasi Asimetri adalah perbedaan informasi antara manajer tingkat atas dan manajer tingkat bawah yang disebabkan oleh perbedaan sumber atas informasi tersebut. Informasi asimetri ini yang nantinya akan memberikan kesempatan dan mendorong bawahan untuk bersikap oportunitis dengan memperkecil pendapatan dan memperbesar biaya ketika mereka diajak berpartisipasi dalam menyusun anggaran yang nantinya menjadi tanggung jawabnya.

Penekanan Anggaran merupakan kondisi bilamana anggaran dijadikan tolok ukur yang paling dominan dalam pengukuran kinerja pada suatu organisasi. Penekanan anggaran dapat membantu organisasi dalam mencapai tujuannya karena dapat meningkatkan motivasi kerja (Irfan, et al, 2016) .

Komitmen Organisasi adalah dorongan dari dalam individu untuk berbuat sesuatu agar dapat menunjang keberhasilan sesuai dengan tujuan dan lebih mengutamakan kepentingan organisasi (Sari \& Putra, 2017). Komitmen organisasi yang kuat dalam sebuah organisasi dapat mengurangi terjadinya senjangan karena karyawan lebih mengutamakan kepentingan organisasi. Sebaliknya, komitmen organisasi yang kurang akan menimbulkan senjangan karena karyawan mengutamakan kepentingannya sendiri.

Ketidakpastian lingkungan adalah salah satu faktor yang menyebabkan senjangan anggaran. Ketidakpastian lingkungan merupakan persepsi dari anggota organisasi dalam mengantisipasi faktor lingkungan terhadap organisasi. Ketidakpastian lingkungan yang tinggi akan menimbulkan senjangan anggaran. Lingkungan yang tidak mudah diprediksi menyebabkan timbulnya senjangan 
Putu Regita Naraswari dan I Made Sukartha. Pengaruh...

anggaran. Sebaliknya, apabila dalam proses penyusunan anggaran lingkungan dapat diprediksi dengan baik maka kemungkinan tidak terjadi senjangan anggaran.

Strategi dibutuhkan untuk menembus pasar yang ada dalam menjalankan sebuah bisnis. Pelaku bisnis harus mengerti betul tujuan untuk menjalankan bisnis dan berapa biaya yang dibutuhkan mencapai tujuan tersebut. Hal ini dapat dibantu dengan membuat anggaran tiap departemen, tentunya dengan proyeksi penjualan dari tahun-tahun sebelumnya untuk dijadikan sebagai acuan. Aspek sumber daya manusia sebagai penyusun dan pelaksana anggaran haruslah dipertimbangkan karena anggaran akan dipengaruhi oleh perilaku manusia terutama bagi pihak yang terlibat langsung dalam penyusunan dan pelaksanaan anggaran. Anggaran dapat memicu tekanan sosial-ekonomi dari para pemangku kepentingan dengan mengalokasikan sumber daya yang memadai untuk menciptakan peluang investasi potensial sementara secara agresif dapat mendorong kepuasan kesejahteraan publik (Yee \& Khin, 2018). Apabila dalam penyusunan anggaran tidak memperhatikan salah satu pihak, atau komunikasi antara bawahan dan atasan kurang berjalan dengan baik, maka kemungkinan bisa mengakibatkan sistem anggaran gagal dikarenakan adanya pihak yang kurang puas dengan anggaran yang telah disusun.

Teori agensi memberikan dasar untuk memahami mengapa seorang individu dapat termotivasi untuk bertindak menciptakan senjangan (Harvey, 2015). Teori keagenan menjelaskan adanya senjangan anggaran dapat dilihat dari adanya konflik kepentingan antara agen (manajer) dan prinsipal (pemilik 
perusahaan). Hubungan agen dan prinsipal diharapkan dapat memfasilitasi proses pengawasan anggaran untuk mencegah perilaku disfungsional (Huseno, 2017). Namun, manajer yang ikut berpartipasi dalam penyusunan anggaran cenderung akan memberikan informasi yang berbeda kepada atasan guna meningkatkan kinerja. Adanya asimetri informasi antara agen dan prinsipal dapat menyebabkan konflik apabila kebijakan pemberian reward didasarkan pada pencapaian anggaran. Manajer akan berusaha keras untuk mencapai target anggaran. Hal inilah yang dapat menyebabkan terjadinya senjangan anggaran.

Beberapa penelitian sebelumnya menunjukan terdapat adanya inkonsistensi dalam hasil penelitian antara variabel independen dengan variabel dependen.

Tabel 4.

Perbedaan Hasil Penelitian Sebelumnya Pada Variabel-Variabel Independen

\begin{tabular}{|c|c|c|}
\hline Variabel Independen & Positif & Negatif \\
\hline Asimetri Informasi & $\begin{array}{l}\text { (Sujana, 2010), (Pello, 2014), } \\
\text { (Ardanari, 2014) }\end{array}$ & $\begin{array}{l}\text { (Bakar, 2014), (Renitasari, } \\
\text { 2017), (Akmal, 2017) }\end{array}$ \\
\hline Penekanan Anggaran & $\begin{array}{l}\text { (Sutanaya, 2018), (Ramona, } \\
\text { 2014), (Renitasari, 2017) }\end{array}$ & $\begin{array}{l}\text { (Sujana, 2010), (Akmal, } \\
\text { 2017) }\end{array}$ \\
\hline Komimen Organisasi & (Alfebriano, 2013) & $\begin{array}{l}\text { (Dianthi, 2017), (Puspitha, } \\
\text { 2017), (Nitiari, 2014) }\end{array}$ \\
\hline Ketidakpastian Lingkungan & $\begin{array}{l}\text { (Alfebriano, 2013), (Nitiari, } \\
\text { 2014), (Untari, 2017) }\end{array}$ & $\begin{array}{l}\text { (Kurniawan, 2015), (Wati, } \\
\text { 2017) }\end{array}$ \\
\hline
\end{tabular}

Perbedaan hasil penelitian yang telah diungkapkan di atas menarik untuk diuji kembali mengingat adanya perbedaan sampel yang digunakan pada penelitian ini.

Jensen dan Meckling (1976) mendefinisikan hubungan keagenan sebagai hubungan kontrak antara prinsipal (yaitu pemegang saham) dan agen (yaitu manajer). Suatu hubungan agency muncul ketika satu atau lebih individu yang 
Putu Regita Naraswari dan I Made Sukartha. Pengaruh...

disebut prinsipal memperkerjakan satu atau lebih individu lain yang disebut agen, untuk melakukan layanan tertentu dan kemudian mendelegasikan otoritas pengambilan keputusan kepada agen. Pihak prinsipal merupakan pihak yang memberikan wewenang dalam mengelola perusahaan kepada pihak agen. Sedangkan, agen merupakan pihak yang diberikan sebagian kekuasaan untuk membuat keputusan bagi kepentingan terbaik prinsipal.

Ketika hubungan kontraktual tersebut terjadi maka akan timbul biaya agensi (agency cost) (Anthony \& Govindarajan, 2007). Biaya agency didefinisikan sebagai biaya yang ditanggung oleh pemegang saham untuk mendorong manajer dalam memaksimalkan kesejahteraan pemegang saham daripada berperilaku mementingkan diri sendiri.

Scott (2000) menyatakan bahwa inti dari Agency Theory atau teori keagenan adalah pendesainan kontrak yang tepat untuk menyelaraskan kepentingan prinsipal dan agen dalam hal terjadi konflik kepentingan. Dalam rangka memotivasi agen maka prinsipal merancang suatu kontrak untuk mengakomodasi kepentingan pihak-pihak yang terlibat dalam kontrak keagenan. Kontrak yang efisien adalah kontrak yang memenuhi dua faktor, yaitu 1) agen dan prinsipal memiliki informasi yang simetris, 2) risiko yang dipikul agen berkaitan dengan imbal jasanya adalah kecil (Sukartha, 2008).

Informasi yang simetris antara agen dan prinsipal tidak pernah terjadi. Hal ini dikarenakan agen sebagai pengendali perusahaan pasti memiliki informasi yang lebih baik dibandingkan prinsipal. Maka dari itu, dibutuhkan kerjasama yang baik antara agen dan prinsipal agar tidak terjadi asimetri informasi. Risiko yang 
dipikul agen berkaitan dengan imbal jasanya adalah kecil, artinya agen mempunyai kepastian yang tinggi mengenai imbalan yang diterimanya. Tindakan agen yang sulit untuk diamati prinsipal akan membuka peluang untuk agen memaksimalkan kepentingannya sendiri dengan melakukan tindakan yang bersifat oportunistis.

Kedua faktor untuk mencapai kontrak yang efisien tidak mudah untuk diwujudkan. Salah satunya adalah informasi yang simetri. Dimana perbedaan informasi antara agen dan prinsipal pasti terjadi. Dengan agen (manajer) yang diberi wewenang oleh prinsipal untuk mengelola perusahaan secara langsung. Sehingga prinsipal memiliki lebih sedikit informasi mengenai perusahaan dan karyawan dibandingkan dengan agen (manajer). Kondisi seperti ini dapat dimanfaatkan oleh agen untuk bertindak opportunistis dengan membuat senjangan pada anggaran.

Teori keagenan menjelaskan perbedaan informasi menyebabkan adanya konflik antara prinsipal dan agen. Kelemahan dari teori keagenan yaitu tidak dapat terpenuhinya salah satu syarat kontrak yang efisien yakni informasi simetri antara agen dan prinsipal. Menurut Pello (2014) asimetri informasi adalah suatu kondisi dimana prinsipal tidak memiliki cukup informasi mengenai kinerja bawahannya, sehingga bawahan mencuri kesempatan dari penganggaran partisipatif dengan cara memberikan informasi yang salah kepada atasannya karena atasan tidak memiliki cukup informasi. Pihak bawahan bisa saja menyembunyikan beberapa bagian informasi yang dia miliki, hal tersebut dapat menimbulkan senjangan anggaran (Dewi \& Erawati, 2014). Asimetri informasi yang rendah antara agen 
Putu Regita Naraswari dan I Made Sukartha. Pengaruh...

dan prinsipal dapat menekan terjadinya senjangan anggaran. Sebaliknya, semakin tinggi asimetri informasi antara agen dan prinsipal dapat meningkatkan terjadinya senjangan anggaran. Beberapa penelitian sebelumnya (Pello, 2014), (Dewi \& Erawati, 2014) (Prasetya \& Muliartha, 2017) menyatakan bahwa semakin tinggi asimetri informasi maka semakin tinggi kemungkinan terjadinya senjangan. Berdasarkan uraian di atas dapat dirumuskan hipotesis sebagai berikut.

$\mathrm{H}_{1}$ : Asimetri Informasi berpengaruh positif pada senjangan anggaran

Teori keagenan merupakan hubungan kontraktual antara agen dan prinsipal. Dimana kontrak yang efisien berisi kepastian yang tinggi terhadap imbalan yang akan diperoleh agen apabila berhasil mencapai target yang telah ditetapkan prinsipal. Apabila prinsipal menerapkan pengukuran kinerja agen dengan melihat pencapaian anggaran, situasi inilah yang disebut dengan penekanan anggaran. Jika bawahan meyakini bahwa keberhasilan pencapaian anggaran akan mendapatkan reward maka bawahan akan berusaha untuk membuat senjangan dalam anggarannya (Erina \& Suartana, 2016). Senjangan anggaran akan terjadi apabila penilaian kinerja bawahan sangat ditentukan oleh anggaran yang disusun, maka bawahan akan berusaha meningkatkan kinerjanya dengan membuat anggaran mudah dicapai dengan melakukan senjangan anggaran (Puspitha \& Suardana, 2017). Apabila bawahan berhasil mencapai target anggaran maka atasan akan memberikan reward. Sebaliknya, apabila bawahan gagal mencapai target anggaran maka atasan akan memberikan sanksi mulai dari tidak mendapatkan bonus sampai pemecatan. Apabila penekanan anggaran diterapkan sangat ketat maka semakin tinggi kemungkinan terjadinya senjangan anggaran. 
Sebaliknya, penekanan anggaran yang diterapkan tidak ketat akan menyebabkan kemungkinan terjadinya senjangan anggaran semakin rendah. Penelitian sebelumnya oleh (Ramona, 2014) , (Renitasari, 2017) dan (Sutanaya \& Sari, 2018) menunjukan bahwa penekanan anggaran berpengaruh positif pada senjangan anggaran. Berdasarkan uraian di atas maka dirumuskan hipotesis sebagai berikut.

$\mathrm{H}_{2}$ : Penekanan anggaran berpengaruh positif pada senjangan anggaran

Agen (manajer) dengan komitmen organisasi yang tinggi akan lebih mementingkan kepentingan organisasi daripada kepentingan individu. Hal ini menunjukkan bahwa agen dengan komitmen organisasi yang tinggi akan melakukan tindakan agar tujuan organisasi tercapai. Agen dengan komitmen organisasi yang tinggi dapat menekan terjadinya asimetri informasi dan dapat memenuhi syarat kontrak yang efisien yaitu informasi simetri antara agen dan prinsipal. Komitmen pada organisasi diartikan sebagai suatu tingkat penerimaan mengenai pekerjaan pada tujuan suatu organisasi dan memiliki kemauan untuk tetap berada dalam organisasi tersebut (Dewi \& Erawati, 2014). Komitmen organisasi yang tinggi dalam diri seorang manajer akan membuat manajer berusaha lebih keras untuk melakukan yang terbaik demi kepentingan organisasi, sebaliknya manajer dengan komitmen organisasi rendah akan mengejar kepentingan pribadinya dengan menggunakan anggaran dan menyebabkan terjadinya senjangan anggaran (Alfebriano, 2013). Hal ini menunjukkan bahwa karyawan dengan komitmen organisasi tinggi akan menggunakan anggaran untuk mencapai tujuan organisasi. Sedangkan, karyawan dengan komitmen organisasi 
Putu Regita Naraswari dan I Made Sukartha. Pengaruh...

rendah akan menggunakan anggaran untuk mencapai kepentingan pribadinya dengan kemungkinan melakukan senjangan cukup tinggi. Pernyataan ini didukung oleh penelitian sebelumnya yang dilakukan oleh (Nitiari \& Yadnyana, 2014), (Puspitha \& Suardana, 2017), dan (Dianthi \& Wirakusuma, 2017) menunjukkan hasil bahwa semakin tinggi komitmen organisasi akan menurunkan terjadinya senjangan anggaran. Berdasarkan uraian tersebut dirumuskan hipotesis sebagai berikut.

$\mathrm{H}_{3}$ : Komitmen organisasi berpengaruh negatif pada senjangan anggaran

Salah satu syarat dari kontrak yang efisien dalam teori keagenan adalah informasi simetris antara agen dan prinsipal. Informasi yang simetri dapat diperoleh dari kondisi lingkungan yang pasti. Apabila ketidakpastian lingkungan terjadi maka akan terjadi asimetri informasi. Ketidakpastian lingkungan merupakan salah satu faktor yang sering menyebabkan organisasi melakukan penyesuaian antara kondisi organisasi dengan lingkungan (Wijayanthi \& Widanaputra, 2013). Kondisi lingkungan yang berubah secara cepat dan dinamis menyebabkan terjadinya keterbatasan informasi yang diterima untuk memprediksi masa depan. Keterbatasan informasi untuk memprediksi masa depan inilah yang menyebabkan terjadinya senjangan. Ketidakpastian lingkungan yang tinggi akan meningkatkan terjadinya senjangan anggaran, sebaliknya ketidakpastian lingkungan yang rendah akan mengurangi terjadinya senjangan anggaran. Penelitian sebelumnya oleh (Nitiari \& Yadnyana, 2014), (Wijayanthi \& Widanaputra, 2013) (Untari, 2017) menyatakan bahwa ketidakpastian lingkungan 
berpengaruh positif dengan senjangan anggaran. Berdasarkan uraian tersebut dirumuskan hipotesis sebagai berikut

$\mathrm{H}_{4}$ : Ketidakpastian Lingkungan berpengaruh positif pada Senjangan Anggaran

\section{METODE PENELITIAN}

Penelitian ini dilakukan di Hotel berbintang Kabupaten Badung. Lokasi ini dipilih karena terdapat fenomena penurunan pertumbuhan kunjungan wisatawan namun tak berdampak pada pendapatan asli daerah kabupaten Badung yang berasal dari pajak hotel. Penelitian ini menggunakan variabel dependen yaitu senjangan anggaran dan variabel independennya yaitu asimetri informasi, penekanan anggaran, komitmen organisasi dan ketidakpastian lingkungan.

Populasi penelitian ini adalah manajer masing-masing departemen hotel berbintang yang berada di Kabupaten Badung. Pertimbangan dalam pemilihan populasi ini karena manajer masing-masing departemen merupakan manajer yang mengetahui lebih banyak informasi di lapangan dibandingkan dengan general manajer dan pemilik hotel. Adapun jumlah hotel berbintang dengan ijin usaha di Kabupaten Badung adalah 97 hotel. Teknik pengambilan sampel yang digunakan dalam penelitian ini adalah metode purposive sampling.

Metode survey dilakukan dengan cara menyebarkan kuesioner secara langsung ke responden di lokasi penelitian. Kuesioner akan disebarkan langsung ke lokasi penelitian yaitu ke hotel berbintang di Kabupaten Badung Selatan berupa pertanyaan-pertanyaan kepada responden mengenai pengaruh asimetri 
Putu Regita Naraswari dan I Made Sukartha. Pengaruh...

informasi, penekanan anggaran, komitmen organisasi dan ketidakpastian lingkungan pada senjangan anggaran.

Teknik analisis data yang digunakan dalam penelitian ini adalah analisis linier berganda. Teknik ini digunakan karena pada penelitian ini menggunakan lebih dari satu variabel bebas dengan satu variabel terikat. Model regresi linear berganda dirumuskan sebagai berikut.

$\mathrm{Y}=\beta_{0}+\beta_{1} X_{1}+\beta_{2} X_{2}+\beta_{3} X_{3}+\beta_{4} X_{4}+\mathrm{e}$

Keterangan:

$\mathrm{Y}=$ Senjangan Anggaran

$\beta_{0}=$ Konstanta

$\beta_{\mathrm{i}}=$ Koefisien Regresi, $\mathrm{i}=1,2,3,4$

$\mathrm{X}_{1}=$ Asimetri Informasi

$\mathrm{X}_{2}=$ Penekanan Anggaran

$\mathrm{X}_{3}=$ Komitmen Organisasi

$\mathrm{X}_{4}=$ Ketidakpastian Lingkungan

$\mathrm{e}=$ standar error

\section{HASIL DAN PEMBAHASAN}

Analisis statistik deskriptif dilakukan dengan mendeskripsikan dan menggambarkan data yang telah dikumpulkan tanpa adanya maksud untuk menarik kesimpulan. Analisis ini digunakan untuk menjelaskan karakteristik sampel terutama mencakup nilai rata-rata, nilai ekstrim yaitu nilai minimum serta standar deviasi dari masing-masing variabel. Berikut hasil dari statistik deskriptif pada Tabel 5 . 
Tabel 5.

Hasil uji analisis statistik deskriptif

\begin{tabular}{lccccc}
\hline & N & Minimum & Maksimum & Mean & $\begin{array}{c}\text { Std. } \\
\text { Deviation }\end{array}$ \\
\hline Asimetri Informasi & 51 & 13 & 28 & 21,10 & 0,562 \\
Penekanan Anggaran & 51 & 13 & 29 & 23,71 & 0,503 \\
Komitmen Organisasi & 51 & 21 & 39 & 31,47 & 0,676 \\
Ketidakpastian & 51 & 34 & 57 & 47,37 & 0,933 \\
Lingkungan & & & & & \\
Senjangan Anggaran & 51 & 13 & 29 & & \\
\hline Sumber: Data diolah, 2018 & & & & &
\end{tabular}

Berdasarkan Tabel 5 di atas dapat dijelaskan bahwa variabel asimetri informasi memiliki nilai minimum 13 dan nilai maksimum 28. Hal ini menunjukkan bahwa nilai terendah dari variabel asimetri informasi yaitu sebesar 13 dimiliki oleh manajer Swiss Bel Hotel Sunset Road. Sedangkan nilai tertinggi sebesar 28 dimiliki oleh manajer Puri Raja Hotel. Secara keseluruhan, nilai ratarata variabel asimetri informasi 21,10 dengan standar deviasi 0,562. Nilai rata-rata sebesar 21,10 menunjukkan bahwa responden pada wilayah pernyataan pada kuesioner cenderung kurang setuju pada masing-masing item pernyataan, artinya range sedang. Dikatakan kurang setuju karena nilai rata-rata 21,10 berada pada poin 3 (sedang) yang dapat dilihat pada lampiran 4 perhitungan range variabel independen dan dependen. Standar deviasi 0,562 berarti bahwa terdapat penyimpangan antara nilai variabel asimetri informasi yang telah diteliti dengan nilai rata-rata 0,562 .

Variabel penekanan anggaran memiliki nilai minimum 13 dan nilai maksimum 29. Hal ini menunjukkan bahwa nilai terendah dari variabel penekanan anggaran yaitu sebesar 13 dimiliki oleh manajer Swiss Bel Hotel Sunset Road. Sedangkan nilai tertinggi sebesar 29 dimiliki oleh manajer The Jayakarta Hotel. Secara keseluruhan, nilai rata-rata variabel penekanan anggaran 23,71 dengan 
Putu Regita Naraswari dan I Made Sukartha. Pengaruh...

standar deviasi 0,503. Nilai rata-rata sebesar 23,71 menunjukkan bahwa responden pada wilayah pernyataan pada kuesioner cenderung setuju pada masing-masing item pernyataan, artinya range tinggi. Dikatakan setuju karena nilai rata-rata 23,71 berada pada poin 4 (tinggi) yang dapat dilihat pada lampiran 4 perhitungan range variabel independen dan dependen. Standar deviasi 0,503 berarti bahwa terdapat penyimpangan antara nilai variabel penekanan anggaran yang telah diteliti dengan nilai rata-rata 0,503.

Variabel Komitmen Organisasi memiliki nilai minimum 21 dan nilai maksimum 39. Hal ini menunjukkan bahwa nilai terendah dari variabel komitmen organisasi yaitu sebesar 21 dimiliki oleh manajer Adhi Jaya Hotel. Sedangkan nilai tertinggi sebesar 39 dimiliki oleh manajer The Jayakarta Hotel. Secara keseluruhan, nilai rata-rata variabel komitmen organisasi 31,47 dengan standar deviasi 0,676. Nilai rata-rata sebesar 31,47 menunjukkan bahwa responden pada wilayah pernyataan pada kuesioner cenderung kurang setuju pada masing-masing item pernyataan, artinya range sedang. Dikatakan kurang setuju karena nilai ratarata 31,47 berada pada poin 3 (sedang) yang dapat dilihat pada lampiran 4 perhitungan range variabel independen dan dependen. Standar deviasi 0,676 berarti bahwa terdapat penyimpangan antara nilai variabel komitmen organisasi yang telah diteliti dengan nilai rata-rata 0,676

Variabel ketidakpastian lingkungan memiliki nilai minimum 34 dan nilai maksimum 57. Hal ini menunjukkan bahwa nilai terendah dari variabel ketidakpastin lingkungan yaitu sebesar 34 dimiliki oleh manajer Ibis Bali Kuta. Sedangkan nilai tertinggi sebesar 57 dimiliki oleh manajer The Jayakarta Hotel. 
Secara keseluruhan, nilai rata-rata variabel ketidakpastian lingkungan 47,37 dengan standar deviasi 0,933. Nilai rata-rata sebesar 47,37 menunjukkan bahwa responden pada wilayah pernyataan pada kuesioner cenderung kurang setuju pada masing-masing item pernyataan, artinya range sedang. Dikatakan kurang setuju karena nilai rata-rata 47,37 berada pada poin 3 (sedang) yang dapat dilihat pada lampiran 4 perhitungan range variabel independen dan dependen. Standar deviasi 0,933 berarti bahwa terdapat penyimpangan antara nilai variabel ketidakpastian lingkungan yang telah diteliti dengan nilai rata-rata 0,933 .

Variabel senjangan anggaran memiliki nilai minimum 13 dan nilai maksimum 29. Hal ini menunjukkan bahwa nilai terendah dari variabel senjangan anggaran yaitu sebesar 13 dimiliki oleh manajer Swiss-Bel Hotel Sunset Road. Sedangkan nilai tertinggi sebesar 29 dimiliki oleh manajer Adhi Jaya Hotel. Secara keseluruhan, nilai rata-rata variabel ketidakpastian lingkungan 22,76 dengan standar deviasi 0,570 . Nilai rata-rata sebesar 22,76 menunjukkan bahwa responden pada wilayah pernyataan pada kuesioner cenderung kurang setuju pada masing-masing item pernyataan, artinya range sedang. Dikatakan kurang setuju karena nilai rata-rata 22,76 berada pada poin 3 (sedang) yang dapat dilihat pada lampiran 4 perhitungan range variabel independen dan dependen. Standar deviasi 0,570 berarti bahwa terdapat penyimpangan antara nilai variabel senjangan anggaran yang telah diteliti dengan nilai rata-rata 0,570 .

Analisis ini dilakukan untuk mengetahui pengaruh asimetri informasi, penekanan anggaran, komitmen organisasi dan ketidakpastian lingkungan pada 
Putu Regita Naraswari dan I Made Sukartha. Pengaruh...

senjangan anggaran. Berikut hasil analisis regresi linier berganda dapat dilihat pada Tabel 6.

Tabel 6.

Hasil Analisis Regresi Linier Berganda

\begin{tabular}{|c|c|c|c|c|c|}
\hline \multirow[t]{2}{*}{ Variabel } & \multicolumn{2}{|c|}{ Unstandardized } & \multirow{2}{*}{$\begin{array}{c}\text { Standardized } \\
\text { Coefficients } \\
\text { Beta }\end{array}$} & \multirow[t]{2}{*}{$\mathbf{t}$} & \multirow[t]{2}{*}{ Sig. } \\
\hline & B & $\begin{array}{c}\text { Std. } \\
\text { Error }\end{array}$ & & & \\
\hline (Constant) & 5,371 & 3,903 & & 1,376 & 0,175 \\
\hline Asimetri Informasi & 0,374 & 0,103 & 0,369 & 3,616 & 0,001 \\
\hline Penekanan Anggaran & 0,264 & 0,127 & 0,233 & 2,081 & 0,043 \\
\hline Komitmen Organisasi & $-0,143$ & 0,067 & $-0,170$ & $-2,135$ & 0,038 \\
\hline Ketidakpastian Lingkungan & 0,164 & 0,065 & 0,268 & 2,512 & 0,016 \\
\hline $\mathrm{R}$ & & & & & $0,908^{\circ}$ \\
\hline R Square & & & & & 0,825 \\
\hline Adjusted Square & & & & & 0,810 \\
\hline F hitung & & & & & 54,246 \\
\hline Sig.F & & & & & $0,000^{2}$ \\
\hline
\end{tabular}

Sumber: Data diolah, 2018

Berdasarkan hasil analisis linier berganda pada Tabel 2 dapat disusun persamaan sebagai berikut:

$$
Y=5,371+0,374 X_{1}+0,264 X_{2}-0,143 X_{3}+0,164 X_{4}+e
$$

Keterangan :

$\mathrm{Y}=$ Senjangan Anggaran

$\mathrm{X}_{1}=$ Asimetri Informasi

$\mathrm{X}_{2}=$ Penekanan Anggaran

$\mathrm{X}_{3}=$ Komitmen Organisasi

$\mathrm{X}_{4}=$ Ketidakpastian Lingkungan

Nilai konstanta sebesar 5,371 $(0,175)$ menunjukkan bahwa apabila nilai asimetri informasi $\left(X_{1}\right)$, penekanan anggaran $\left(X_{2}\right)$, komitmen organisasi $\left(X_{3}\right)$, dan ketidakpastian lingkungan $\left(\mathrm{X}_{4}\right)$ sama dengan nol. Maka, tidak terjadi senjangan anggaran.

Nilai koefisien $\beta_{1}=0,374(0,001)$ menunjukkan bahwa apabila nilai asimetri informasi $\left(\mathrm{X}_{1}\right)$ meningkat, maka nilai dari senjangan anggaran (Y) akan meningkat dengan asumsi variabel lainnya konstan. 
Nilai koefisien $\beta_{2}=0,264(0,43)$ menunjukkan bahwa apabila nilai penekanan anggaran $\left(\mathrm{X}_{2}\right)$ meningkat, maka nilai dari senjangan anggaran $(\mathrm{Y})$ akan meningkat dengan asumsi variabel lainnya konstan.

Nilai koefisien $\beta_{3}=-0,143(0,38)$ menunjukkan bahwa apabila nilai komitmen organisasi $\left(\mathrm{X}_{3}\right)$ meningkat, maka nilai dari senjangan anggaran $(\mathrm{Y})$ akan menurun dengan asumsi variabel lainnya konstan.

Nilai koefisien $\beta_{4}=0,164(0,16)$ menunjukkan bahwa apabila nilai ketidakpastian lingkungan $\left(\mathrm{X}_{4}\right)$ meningkat, maka nilai dari senjangan anggaran (Y) akan meningkat dengan asumsi variabel lainnya konstan.

Koefisien determinasi berguna untuk mengukur seberapa jauh kemampuan model dalam menerangkan variansi variabel dependen yang dapat dilihat dari nilai Adjusted $R$ Square pada Tabel 6. Berdasarkan tabel tersebut nilai dari Adjusted $R$ Square adalah 0,810 yang berarti sebesar 81 persen variansi senjangan anggaran mampu dijelaskan oleh variabel asimetri informasi, penekanan anggaran, komitmen organisasi dan ketidakpastian lingkungan, sedangkan 19 persen sisanya dijelaskan oleh faktor lain diluar model penelitian ini.

Uji F digunakan untuk mengetahui kelayakan model regresi sebagai alat untuk dianalisis yang menguji pengaruh variabel independen secara serempak terhadap variabel dependen. Bila nilai sig. dari $\mathrm{F} \leq \alpha$ sebesar $5 \%$, maka memenuhi syarat untuk uji kelayakan model. Dapat dilihat pada Tabel 6 bahwa nilai signifikansi sebesar 0,000 lebih kecil dari $\alpha=0,05$. Sehingga dapat dikatakan bahwa model regresi ini sudah tepat digunakan untuk melakukan prediksi. 
Putu Regita Naraswari dan I Made Sukartha. Pengaruh...

Dapat dilihat pada Tabel 6 koefisien asimetri informasi bernilai positif 0,374 dengan nilai signifikansi sebesar 0,001 lebih kecil dari Alpha 0,05. Berdasarkan hasil tersebut dapat disimpulkan bahwa $\mathrm{H}_{0}$ ditolak dan $\mathrm{H}_{1}$ diterima, ini berarti asimetri informasi berpengaruh positif pada senjangan anggaran.

Koefisien penekanan anggaran bernilai positif 0,264 dengan nilai signifikansi sebesar 0,043 lebih kecil dari Alpha 0,05. Berdasarkan hasil tersebut dapat disimpulkan bahwa $\mathrm{H}_{0}$ ditolak dan $\mathrm{H}_{2}$ diterima, ini berarti penekanan anggaran berpengaruh positif pada senjangan anggaran.

Koefisien komitmen organisasi bernilai negatif 0,143 dengan nilai signifikansi sebesar 0,038 lebih kecil dari Alpha 0,05. Berdasarkan hasil tersebut dapat disimpulkan bahwa $\mathrm{H}_{0}$ ditolak dan $\mathrm{H}_{3}$ diterima, ini berarti komitmen organisasi berpengaruh negatif pada senjangan anggaran.

Koefisien ketidakpastian lingkungan bernilai positif 0,164 dengan nilai signifikansi sebesar 0,016 lebih kecil dari Alpha 0,05. Berdasarkan hasil tersebut dapat disimpulkan bahwa $\mathrm{H}_{0}$ ditolak dan $\mathrm{H}_{4}$ diterima, ini berarti ketidakpastian lingkungan berpengaruh positif pada senjangan anggaran.

Pengujian hipotesis yang telah dilakukan menunjukkan bahwa asimetri informasi berpengaruh positif pada senjangan anggaran. Berdasarkan hasil pengujian hipotesis tersebut maka dapat disimpulkan bahwa asimetri informasi berpengaruh positif pada senjangan anggaran di Hotel berbintang yang ada di Kabupaten Badung. Teori keagenan menjelaskan bahwa perbedaan informasi dapat menyebabkan konflik antara agen dan prinsipal. Sehingga perbedaan informasi dapat menyebabkan terjadinya senjangan anggaran. Semakin tinggi 
asimetri informasi yang terjadi maka semakin tinggi pula senjangan anggaran yang terjadi. Hal ini berarti bahwa semakin tinggi perbedaan informasi yang dimiliki antara agen dan prinsipal maka semakin tinggi pula peluang untuk melakukan senjangan anggaran. Hasil penelitian ini mendukung teori keagenan dalam menjelaskan pengaruh asimetri informasi pada senjangan anggaran. Hasil penelitian ini juga sejalan dengan penelitian sebelumnya yang dilakukan oleh (Pello, 2014), (Dewi \& Erawati, 2014) dan (Prasetya \& Muliartha, 2017).

Pengujian hipotesis yang telah dilakukan menunjukkan bahwa penekanan anggaran berpengaruh positif pada senjangan anggaran. Berdasarkan hasil pengujian tersebut maka dapat disimpulkan bahwa penekanan anggaran berpengaruh positif pada senjangan anggaran di Hotel berbintang yang ada di Kabupaten Badung. Teori keagenan yang menjelaskan bahwa apabila prinsipal mengukur kinerja agen hanya dengan menggunakan anggaran maka hal tersebut dapat menyebabkan terjadinya senjangan anggaran. Semakin tinggi penekanan anggaran yang terjadi maka semakin tinggi pula senjangan anggaran. Hal ini berarti bahwa semakin tinggi pengukuran kinerja dengan menggunakan anggaran maka semakin tinggi pula peluang individu untuk melakukan senjangan anggaran. Hasil penelitian ini mendukung teori keagenan dalam menjelaskan pengaruh penekanan anggaran pada senjangan anggaran. Hasil penelitian ini juga sejalan dengan penelitian sebelumnya yang dilakukan oleh (Ramona, 2014), (Renitasari, 2017) dan (Sutanaya \& Sari, 2018).

Pengujian hipotesis yang telah dilakukan menunjukkan bahwa komitmen organisasi berpengaruh negatif pada senjangan anggaran. Berdasarkan hasil 
Putu Regita Naraswari dan I Made Sukartha. Pengaruh...

pengujian tersebut maka dapat disimpulkan bahwa komitmen organisasi berpengaruh negatif pada senjangan anggaran di Hotel berbintang yang ada di Kabupaten Badung. Teori keagenan menjelaskan bahwa agen dengan komitmen yang tinggi terhadap organisasi dapat menekan terjadinya senjangan anggaran. Semakin tinggi komitmen organisasi maka semakin rendah senjangan anggaran. Hal ini berarti bahwa semakin tinggi kepercayaan individu karyawan pada perusahaan maka semakin rendah peluang individu untuk melakukan senjangan anggaran. Hasil penelitian ini mendukung teori keagenan dalam menjelaskan pengaruh komitmen organisasi pada senjangan anggaran. Hasil penelitian ini juga sejalan dengan penelitian sebelumnya yang dilakukan oleh (Nitiari \& Yadnyana, 2014), (Puspitha \& Suardana, 2017), dan (Dianthi \& Wirakusuma, 2017).

Pengujian hipotesis yang telah dilakukan menunjukkan bahwa ketidakpastian lingkungan berpengaruh positif pada senjangan anggaran. Berdasarkan hasil pengujian tersebut dapat disimpulkan bahwa ketidakpastian lingkungan berpengaruh positif pada senjangan anggaran di Hotel berbintang yang ada di Kabupaten Badung. Teori keagenan menjelaskan bahwa kondisi lingkungan yang tidak pasti dapat menyebabkan terjadinya perbedaan informasi yang dapat menyebabkan terjadinya senjangan anggaran. Semakin tinggi ketidakpastian lingkungan maka semakin tinggi pula senjangan anggaran. Hal ini berarti bahwa semakin tinggi perubahan kondisi lingkungan yang terjadi maka semakin tinggi pula peluang terjadinya senjangan anggaran. Hasil penelitian ini mendukung teori keagenan dalam menjelaskan pengaruh ketidakpastian lingkungan pada senjangan anggaran. Hasil penelitian ini juga sejalan dengan 
penelitian sebelumnya yang dilakukan oleh (Nitiari \& Yadnyana, 2014), (Wijayanthi \& Widanaputra, 2013) dan (Untari, 2017).

Penelitian ini dilakukan untuk mendukung teori keagenan dalam menjelaskan pengaruh asimetri informasi, penekanan anggaran, komitmen organisasi dan ketidakpastian lingkungan pada senjangan anggaran. Berdasarkan hasil uji dalam penelitian ini dapat diketahui bahwa teori keagenan mampu menjelaskan pengaruh asimetri informasi, penekanan anggaran, komitmen organisasi dan ketidakpastian lingkungan pada senjangan anggaran.

Berdasarkan hasil penelitian ini maka pihak pihak hotel berbintang di Kabupaten Badung perlu memerhatikan faktor asimetri informasi, penekanan anggaran, komitmen organisasi serta ketidakpastian lingkungan dalam proses penyusunan anggaran. Asimetri informasi dan ketidakpastian lingkungan perlu mendapatkan perhatian lebih agar keputusan yang diambil tidak menguntungkan salah satu pihak. Perbedaan informasi yang dimiliki atasan dan bawahan perlu ditekan serta perlu adanya antisipasi pihak manajer dalam menghadapi perubahan informasi yang sulit diprediksi. Pihak manajer juga perlu memerhatikan lebih baik karyawannya dalam bekerja, penilaian kinerja karyawan tidak seharusnya dinilai hanya berdasarkan anggaran yang dapat dicapai. Selain itu, manajer hendaknya mampu menciptakan suasana yang nyaman bagi karyawan dalam bekerja sehingga karyawan menjadi termotivasi dan memiliki komitmen yang baik dengan perusahaan. 
Putu Regita Naraswari dan I Made Sukartha. Pengaruh...

\section{SIMPULAN}

Asimetri informasi berpengaruh positif pada senjangan anggaran di Hotel berbintang Kabupaten Badung. Hal ini berarti bahwa semakin tinggi perbedaan informasi yang dimiliki agen dan prinsipal maka semakin tinggi pula senjangan anggaran yang terjadi.

Penekanan anggaran berpengaruh positif pada senjangan anggaran di Hotel berbintang Kabupaten Badung. Hal ini berarti bahwa semakin ketat pengukuran kinerja dengan menggunakan anggaran maka semakin tinggi pula senjangan anggaran yang terjadi.

Komitmen organisasi berpengaruh negatif pada senjangan anggaran di Hotel berbintang Kabupaten Badung. Hal ini berarti bahwa semakin tinggi komitmen organisasi dalam diri karyawan maka semakin rendah senjangan anggaran yang terjadi.

Ketidakpastian lingkungan berpengaruh positif pada senjangan anggaran di Hotel berbintang Kabupaten Badung. Hal ini berarti bahwa semakin tinggi perubahan kondisi lingkungan maka semakin tinggi pula senjangan anggaran yang terjadi.

Asimetri informasi merupakan salah satu faktor yang dapat menyebabkan terjadinya senjangan anggaran. Asimetri informasi yang cukup tinggi terjadi pada Puri Raja Hotel. Maka dari itu, Puri Raja Hotel perlu menekan terjadinya asimetri informasi antara atasan dan bawahan. Pihak hotel dapat meminimalisir perbedaan informasi yang terjadi dengan menciptakan komunikasi yang baik antara atasan dan bawahan. Serta perlu adanya transparansi informasi antara atasan dan 
bawahan terutama pada pihak-pihak yang berpartisipasi pada penyusunan anggaran.

Penekanan anggaran merupakan salah satu faktor yang dapat menyebabkan terjadinya senjangan anggaran. Penekanan anggaran yang cukup tinggi terjadi pada The Jayakarta Hotel. Maka dari itu, The Jayakarta Hotel perlu memerhatikan kinerja karyawannya dengan baik. Pihak hotel sebaiknya tidak menjadikan anggaran sebagai tolok ukur satu-satunya terhadap penilaian kinerja karyawan. Kinerja karyawan dapat diukur melalui prestasi, perilaku serta tingkat kehadiran karyawan tersebut.

Komitmen organisasi dapat menjadi salah satu faktor terjadinya senjangan anggaran. Komitmen organisasi yang rendah dimiliki oleh Swiss-Bel Hotel Sunset Road. Maka dari itu, pihak hotel perlu menumbuhkan komitmen dalam individu karyawan. Pihak hotel sebaiknya menciptakan suasana yang nyaman serta dapat memotivasi karyawan di lingkungan kerja. Pihak hotel dapat memberikan reward pada karyawan atas capaian kerjanya untuk memotivasi karyawan. Dengan suasana yang nyaman dan menghargai kinerja karyawan dengan memberikan reward dapat menumbuhkan komitmen dalam individu karyawan.

Ketidakpastian lingkungan menjadi salah satu faktor terjadinya senjangan anggaran. Ketidakpastian lingkungan yang paling tinggi terjadi pada The Jayakarta Hotel. Maka dari itu, pihak hotel perlu mengantisipasi terjadinya perubahan kondisi lingkungan kerja. Dengan cara pihak hotel menciptakan suasana yang nyaman bagi karyawan, seperti dengan menyediakan fasilitas yang diperlukan oleh karyawan. 
Putu Regita Naraswari dan I Made Sukartha. Pengaruh...

Bagi peneliti selanjutnya diharapkan dapat melakukan penelitian di hotel dengan daerah yang berbeda agar menjadi lebih tergeneralisasi. Selain itu, peneliti selanjutnya dapat mempertimbangkan variabel lain yang dapat menyebabkan senjangan anggaran, seperti karakter personal dan self esteem.

\section{REFERENSI}

Akmal, M. (2017). Pengaruh Partisipasi Anggaran, Asimetri Informasi dan Penekanan Anggaran Terhadap Senjangan Anggaran (Studi Pada Kantor Pengawasan dan Pelayanan Bea dan Cukai Makassar). Universitas Hasanuddin.

Alfebriano. (2013). Faktor-faktor yang Mempengaruhi Slack Anggaran Pada PT. BRI di Kota Jambi. E-Jurnal Binar Akuntansi, 2(1), 12-22.

Anthony, R. N., \& Govindarajan, V. (2007). Management control system - 12th ed. McGraw-Hill International Edition.

Ardanari, I. G. A. A. C., \& Putra, A. (2014). Pengaruh Partisipasi Penganggaran , Asimetri Informasi, Self Estee Dan Budget Emphasis Pada Budgetary Slack. E-Jurnal Akuntansi Universitas Udayana, 7(3), 700-715.

Bakar, N. R. binti A. (2014). Impact of Organisational Factors on Budgetary Slack. E-Proceedings of the Conference on Management and Muamalah, (May), 26-27.

Dewi, N. P., \& Erawati, N. M. A. (2014). Pengaruh Partisipasi Penganggaran, Informasi Asimetri, Penekanan Anggaran dan Komitmen Organisasi Pada Senjangan Anggaran. E-Jurnal Akuntansi Universitas Udayana, 9(2), 476486.

Dianthi, I. A. G. P., \& Wirakusuma, M. G. (2017). Pengaruh Partisipasi Penganggaran, Asimetri Informasi, Budaya Organisasi Dan Komitmen Organisasi Pada Senjangan Anggaran. E-Jurnal Akuntansi Universitas Udayana ISSN : 2302-8556, 18(Vol.18.2), 874-901.

Erina, N. P. D., \& Suartana, W. (2016). Pengaruh Partisipasi Penganggaran, Penekanan Anggaran, Kapasitas Individu, dan Kejelasan Sasaran Anggaran pada Senjangan Anggaran. E-Jurnal Ekonomi Dan Bisnis Universitas Udayana, 15(2), 973-1000. 
Gilbert-Carreras, M., Naranjo-Gil, D., \& Gago, S. (2014). Trust in Superiors and Dysfunctional Behaviors: an Experimental Study on Budgetary Slack. Journal of Positive Management, Vol. 5(1), 54-66.

Hansen \& Mowen. (2012). Akuntansi Manajerial Buku I Edisi 8. Jakarta :Salemba Empat

Harvey, M. E. (2015). On Organizational Budget Slack: An Empirical Examination, 13(1), 83-90.

Huseno, T. (2017). Organization Commitment and Environmental Uncertainty Moderating Budget Participation on Budgetary Slack, 106(1), 106-115.

Irfan, M., Santoso, B., \& Effendi, L. (2016). Pengaruh Partisipasi Anggaran terhadap Senjangan Anggaran dengan Asimetri Informasi, Penekanan Anggaran dan Komitmen Organisasional sebagai Variabel Pemoderasi. Jurnal Akuntansi Dan Investasi, 17(2), 158-175.

Jensen, M. C., \& Meckling, W. H. (1976). Theory of the firm: Managerial behavior, agency costs and ownership structure. Journal of Financial Economics, 3(4), 305-360.

Kurniawan, Y. (2015). Pengaruh Asimetri Informasi, Kecukupan Anggaran, Komitmen Organisasi dan Ketidakpastian Lingkungan Terhadap Hubungan Partisipasi Anggaran Dengan Senjangan Anggaran (Studi Empiris Pada Satuan Kerja Perangkat Daerah Kota Dumai). Faculty of Economics Riau University, 2(1), 1-15.

Negara, P. R. S., \& Wirajaya, I. G. A. (2018). Pengaruh Partisipasi Penyusunan Anggaran pada Budgetary Slack dengan Komitmen Organisasi , Opportunistic Behavior dan Ketidakpastian Lingkungan Sebagai Pemoderasi. E-Jurnal Akuntansi Universitas Udayana, 22(3), 2339-2367. 6

Nitiari, N. L. N., \& Yadnyana, K. (2014). Pengaruh Partisipasi Penganggaran, Komitmen Organisasi dan Ketidakpastian Lingkungan Pada Senjangan Anggaran. E-Jurnal Akuntansi Universitas Udayana, 9(3), 829-841.

Pello, E. V. (2014). Pengaruh Asimetri Informasi dan Locus of Control Pada Hubungan Antara Penganggaran Partisipatif Dengan Senjangan Anggaran. E-Jurnal Uniersitas Udayana, 6(2), 287-305.

Prasetya, I. B. A. A., \& Muliartha, K. (2017). Pengaruh Partisipasi Anggaran, Job Relevant Information dan Asimetri Informasi Pada Budget Slack, 20, 15641591. 
Puspitha, D. M. A. P., \& Suardana, K. A. (2017). Faktor-Faktor yang Mempengaruhi Senjangan Anggaran di SKPD Kabupaten Karangasem Bali. E-Jurnal Akuntansi Universitas Udayana, 21(1), 800-829.

Ramona, F. D. A. (2014). Pengaruh Self Esteem, Budget Emphasis, dan Locus Of Control Terhadap Slack Anggaran. Fakultas Ekonomi Dan Bisnis Universitas Dian Nuswantoro Semarang, 1-16.

Renitasari, Y. (2017). Keadilan Prosedural dan Iklim Kerja Etis Sebagai Pemoderasi Pengaruh Partisipasi Anggaran, Penekanan Anggaran dan Asimetri Informasi Terhadap Kesenjangan Anggaran.

Sari, N. L. E. Y., \& Putra, A. (2017). Kapasitas Individu, Self Esteem, Komitmen Organisasi, dan Penekanan Anggaran Memoderasi Partisipasi Penganggaran Pada Senjangan Anggaran. E-Jurnal Akuntansi Universitas Udayana, 20, 1189-1218.

Scott, W. R. (2000). Financial Accounting Theory. Learning.

Sujana, I. K. (2010). Pengaruh partisipasi penganggaran, penekanan anggaran, komitmen organisasi, asimetri informasi, dan ketidakpastian lingkungan terhadap budgetary slack pada hotel-hotel berbintang di Kota Denapasar. Jurnal Ilmiah Akuntansi Dan Bisnis, 1-26.

Sukartha, I. M. (2008). Pengaruh Manajemen Laba, dan Kepemilikan Manajerial pada Kesejahteraan Pemegang Saham Perusahaan Target Akuisisi. Jurnal Ilmiah Akuntansi Dan Bisnis Universitas Udayana, 1(3), 1-25.

Sutanaya, I. M., \& Sari, M. M. R. (2018). Pengaruh Partisipasi Anggaran, Penekanan Anggaran dan Rencana Kompensasi Terhadap Senjangan Anggaran. E-Jurnal Akuntansi Universitas Udayana, 22(1), 775-803.

Thien, T Hiep. (2014). Factors Affecting the Propensity to Create Budgetary Slack Evidence from Vietnamese Enterprises. Journal of Economic Development, 22(221), 100-124.

Untari, D. (2017). Pengaruh Partisipasi Anggaran, Asimetri Informasi, Locus of Control, Penekanan Anggaran, dan Ketidakpastian Lingkungan Terhadap Senjangan Anggaran (Studi Empiris Pada SKPD Kabupaten Bengkalis). Faculty of Economics Riau University, 4(1).

Van Der Stede, W. A. (2001). The effect of corporate diversification and business unit strategy on the presence of slack in business unit budgets. Accounting, Auditing \& Accountability Journal. 
Wati, N. P. D. L. S., \& Damayanthi, I. G. A. E. (2017). Pengaruh Partisipasi Penganggaran, Asimetri Informasi, Ketidakpastian Lingkungan dan Budget Emphasis Pada Senjangan Anggaran. E-Jurnal Akuntansi Universitas Udayana, 21(3), 2311-2337.

Wijayanthi, P. K., \& Widanaputra, A. A. G. P. (2013). Pengaruh Partisipasi Penganggaran Pada Senjangan Anggaran Dengan Kepercayaan Diri dan Ketidakpastian Lingkungan Sebagai Pemoderasi. E-Jurnal Akuntansi Universitas Udayana, 29(3), 190-195.

Yee, C. M., \& Khin, E. W. S. (2018). Determinants of e mployees' psychological ownership on budgetary slack, 1(1), 122-130. 